\title{
Електроміографічні дослідження хворих з немоторними проявами хвороби Паркінсона
}

\author{
УДК 619:612,741:616.858
}

\section{А. Й. Лабінський}

Львівський національний університет ветеринарної медицини та біотехнологій імені С. З. Ґжицького, Львів, Україна

\begin{abstract}
Резюме. У науковій літературі широко описано різноманітні методи лікування осіб із хворобою Паркінсона, кількість яких останнім часом збільшується. Мета. Провести та оцінити електроміографічні дослідження хворих з немоторними проявами хвороби Паркінсона під час фізичної терапії. Методи. Аналіз наукової літератури, електроміографічні дослідження, методи фізичної терапії. Результати. В роботі проаналізовано дані обстеження та фізичного реабілітаційного лікування пацієнтів з немоторними проявами хвороби Паркінсона. Доведено значне покращення показників електроміографії після фізичної терапії у хворих з немоторними проявами хвороби Паркінсона. За даними електроміографічних досліджень виявлено, що фізична терапія покращує стан хворих з немоторними проявами хвороби Паркінсона, що дозволяє рекомендувати її для широкого впровадження.
\end{abstract}

Ключові слова: електроміографія, хвороба Паркінсона, лікувальні фізичні вправи.

\section{Electromyographic studies of patients with non-motor manifestations of Parkinson's disease}

\section{A. I. Labinskyy}

Lviv National University of Veterinary Medicine and Biotechnology named after S.Z. Gzhytsky, Lviv, Ukraine

\begin{abstract}
A variety of treatment methods for patients with Parkinson's disease, the number of which has recently increased, are extensively described in scientific literature. Objective. Conduct and evaluate electromyographic studies of patients with non-motor manifestations of Parkinson's disease during physical therapy. Methods. Analysis of the scientific literature of the disease, electromyographic research methods of physical therapy. Results. The paper analyzes the data of examination and physical rehabilitation treatment of patients with non-motor manifestations of Parkinson's disease. A significant improvement in electromyography indices after physical therapy in patients with non-motor manifestations of Parkinson's disease has been shown. Electromyographic studies revealed that physical therapy improves the condition of patients with non-motor manifestations of Parkinson's disease, which allows recommending it for widespread use. Keywords: electromyography, Parkinson's disease, therapeutic physical exercises.
\end{abstract}

Постановка проблеми. Незважаючи на численні існуючі схеми діагностики та лікування хворих із хворобою Паркінсона, особливо з немоторними її проявами, інвалідизація при вказаній патології в останні роки продовжує зростати $[1,3,7,8]$. У доступній науковій літературі досить широко описано різноманітні методи досліджень та лікування осіб із хворобою Паркінсона, зокрема фрізичні, біохімічні та інші методи досліджень під час занять лікувальною фрізичною культурою (ЛФК), а також існують рекомендації до самообслуговування та тренування ходьби [1].
Однак недостатньо досліджень, в яких вивчаються електроміографічні показники при фрізичній терапії хвороби Паркінсона. Електроміографрія (ЕМГ) вважається високоінформативним методом визначення наростаючих з віком клінічних симптомів екстрапірамідної недостатності. Важливою іiї перевагою для діагностики паркінсонізму $є$ висока чутливість при виявленні субклінічних і початкових проявів захворювання [2].

Під час оцінювання ефективності протипаркінсонічної терапії дуже важливо аналізувати не тільки якісні, а й кількісні характеристики ЕМГ, 
що дозволяє продуктивно здійснювати індивідуальну корекцію лікування та прогнозувати перебіг захворювання [4-6].

Роботу виконано в межах науково-дослідної роботи кафедри реабілітації та здоров'я людини Львівського національного університету ветеринарної медицини та біотехнологій імені С. 3. Ґжицького на тему «Особливості фрізичної терапії захворювань екстрапірамідної нервової системи та церебральних транзиторних ішемічних нападів і супутніх синдромів» (номер держреєстрації 0120U100690).

Мета дослідження - провести аналіз еоективності програми фрізичної терапії.

Методи дослідження: аналіз наукової літератури, електроміографрічні дослідження, методи орізичної терапії.

Результати дослідження та їх обговорення. Було проведено дослідження трьох груп хворих $з$ хворобою Паркінсона за допомогою ЕМГ у пацієнтів, які перебували на реабілітаційному лікуванні на клінічних базах кафедри реабілітації і здоров'я людини Львівського національного університету ветеринарної медицини та біотехнологій імені С. З. Ґжицького до і після проведення курсової фрізичної терапії.

ЕМГ застосовували як контроль функціонального стану біоелектричної активності м'язів у хворих на хворобу Паркінсона. Реєстрували поверхневу ЕМГ згиначів і розгиначів передпліччя правої і лівої руки - двоголового (biceps brachii) і триголового (triceps brachii) м'язів плеча. Для відведення ЕМГ використовували біполярні нашкірні електроди $з$ постійною межелектродною відстанню 1,5 см. Біоелектричні сигнали подавали по чотирьох каналах на підсилювачі електроміографра «Медікор» MG 440 з пропускною здатністю 2 Гц - 10 кГц. Далі через аналого-цифровий перетворювач вони надходили в комп'ютер і запис проводився на жорсткий диск. Під час дослідження хворий лежав на спині, руки - на горизонтальній поверхні. Запис ЕМГ здійснювали:

1) у стані спокою (звертаючи особливу увагу на розслаблення кінцівок);

2) при дозованому навантаженні - утримання вантажу вагою 2 кг на піднятій вгору і витягнутій вперед руці протягом 5 с.

ЕМГ спокою використовували для оцінювання здатності до розслаблення м'язового напруження; при цьому по кожному каналу будували гістограми, за допомогою курсора вибирали безартефактні ділянки запису. Амплітуду перераховували від піку до піку, починаючи 33 мкВ. Середнє значення амплітуди визначали на основі 100 вимірювань, а максимальне значення амп- літуди відповідало піковій амплітуді, наявній на обраному відрізку запису. Використання методу побудови, що огинає амплітуду ЕМГ, дозволило виявляти наявність ритмічних залпових розрядів. Використаний метод комп'ютеризованого аналізу ЕМГ досить ефективний для отримання кількісної характеристики ЕМГ ознак хвороби Паркінсона й об'єктивного оцінювання дії фрізичної терапії.

Аналіз ЕМГ-параметрів у хворих із хворобою Паркінсона проводили на більш ураженому боці. У 26 пацієнтів мав місце переважно лівобічний прояв симптомів. Клінічна симптоматика у 41 пацієнта проявлялася за правобічним гемотипом і у 20 пацієнтів була двобічною.

Для покращення рухових функцій і поступальної стійкості застосовували терапевтичні вправи на тренування опору та м'язової сили. Тренування проводили тричі на тиждень протягом восьми тижнів 3 поступовим збільшенням навантаження та переходом 3 четвертого тижня до тренувань на біговій доріжці і велотренажері. Заняття проводили в інтервальному режимі протягом 30 хв 3 15-хвилинним відпочинком. Пацієнти виконували по 7-8 підходів на біговій доріжці зі швидкістю 60 оберт $\cdot x^{-1}$.

Застосування курсової фрізичної терапії чинило значний позитивний вплив на амплітудні показники ЕМГ у пацієнтів усіх трьох груп. До застосування курсу фрізичної терапії у хворих у спокійному стані відмічалася наявність сплесків біоелектричної м'язової активності. Необхідно зазначити, що у здорових осіб відповідного віку, на відміну від хворих, ЕМГ спокою мала монотонний низькоамплітудний характер.

Усереднені значення Ас спокою у хворих на більш ураженому боці в першій групі становили 12,6 \pm 1,3 мкВ для $m$. biceps brachii i $8,4 \pm 1,4$ мкВ для $m$. triceps brachii. У другій групі цей показник дорівнював 17,5 \pm 3,8 мкВ і 12,5 \pm 3,9 мкВ відповідно. У третій групі реєстрували Ас для $m$. biceps brachii 20,9 \pm 5,7 мкВ і для m. triceps brachii 14,3 \pm 3,7 мкВ (табл. 1).

Для порівняння слід зазначити, що у контрольній групі пацієнтів відповідного віку ( $\mathrm{n}=15)$ Ac зазначених м'язів коливалася в межах 5,0 \pm 0,4 - 6,1 \pm 0,7 мкВ. Після курсу фрізичної терапії амплітуда ЕМГ спокою у хворих достовірно знижувалася. Ас спокою для $m$. biceps brachii на більш ураженому боці після курсу фрізичної терапії у першій групі зменшувалася до 7,2 \pm 0,5 (р $<0,001)$. Значення в другій групі були достовірними і становили 9,0 $\pm 1,5$ ( $p<0,01)$. У третій групі відмічалася така сама позитивна динаміка цього показника $-12,0 \pm 2,7$ мкВ ( $p<0,01)$. 
Спортивна медицина, фізична терапія та ерготерапія № 1, 2021

ТАБЛИЦЯ 1 - Вплив фізичної терапії (ФТ) на середню амплітуду (Ас) електроміографії спокою у хворих із хворобою Паркінсона

\begin{tabular}{|c|c|c|c|c|c|}
\hline \multirow{4}{*}{$\begin{array}{c}\text { Група } \\
\text { Перша }(\mathrm{n}=20)\end{array}$} & \multirow{3}{*}{$\begin{array}{c}\text { Проведення } \\
\text { дослідження }\end{array}$} & \multicolumn{4}{|c|}{ Ac, мкB } \\
\hline & & \multicolumn{2}{|c|}{ на ушкодженому боці } & \multicolumn{2}{|c|}{ на неушкодженому боці } \\
\hline & & $12,6 \pm 1,3$ & $8,4 \pm 1,4$ & $13,9 \pm 3,1$ & $8,1 \pm 0,9$ \\
\hline & після ФТ & $7,2 \pm 0,5^{\star \star *}$ & $6,4 \pm 0,4$ & $6,6 \pm 0,3^{*}$ & $7,5 \pm 1,5$ \\
\hline \multirow[t]{2}{*}{ Друга $(n=26)$} & до ФТ & $17,5 \pm 3,8$ & $12,5 \pm 3,9$ & $15,4 \pm 3,3$ & $18,3 \pm 9,9$ \\
\hline & після ФТ & $9,0 \pm 1,5^{\star *}$ & $8,6 \pm 1,9$ & $9,9 \pm 1,5^{*}$ & $13,5 \pm 6,1$ \\
\hline \multirow[t]{2}{*}{ Третя $(n=41)$} & до ФТ & $20,9 \pm 5,7$ & $14,3 \pm 3,7$ & $17,0 \pm 4,0$ & $15,5 \pm 4,8$ \\
\hline & після ФТ & $12,0 \pm 2,7^{\star \star}$ & $10,5 \pm 2,8^{\star * \star}$ & $11,7 \pm 2,4^{* *}$ & $10,0 \pm 2,6$ \\
\hline
\end{tabular}

Примітки: ${ }^{*}-p<0,05,{ }^{* \star}-p<0,01,{ }^{* \star \star}-p<0,001$.

Зниження амплітуди спокою м'язової активності m. triceps brachii на більш ураженому боці під впливом фрізичної терапії було незначно виражене в першій і другій групах і мало достовірні показники лише в третій групі: 11,7 $\pm 2,4$ мкВ $(p<0,001)$. Виявлялася також позитивна динаміка Ас спокою для згинальних і розгинальних м'язів плеча у хворих на менш ураженому боці, де отримано недостовірні дані, але мала місце тенденція до зниження цих значень.

Паралельно оцінювали показники моторного темпу та простої сенсомоторної реакції у хворих на хворобу Паркінсона на тлі курсового застосування фрізичної терапії. Разом із поліпшенням біоелектричної м'язової активності у хворих після курсового застосування фрізичної терапії спостерігалася тенденція до нормалізації часу рухової реакції. Особливо помітно збільшувався моторний темп, що виражалося у зменшенні часу для послідовного натискання пальцем двох клавіш, рознесених на певну відстань. Цей тест проводили до і після проведення курсу лікування. До проведення час, усереднений для обох рук, становив у першій групі 706,2 \pm 44,8 мс, що різко відрізнялося від такого в контрольній групі (КГ) $-347,7 \pm 21,9$ мс ( $<0,001)$. Значення, отримане при обстеженні другої групи, дорівнювало 681,6 $\pm 27,2$ мс і також достовірно відрізнялося від КГ ( $<0,001)$. У третій групі цей показник становив 745, $6 \pm 31,7$ мс, з тією самою вірогідністю в КГ ( $<<0,001)$ (табл. 2).
Після курсу фрізичної терапії у цих групах відмічалася позитивна динаміка, що виражалося у вигляді зменшення часу моторного темпу.

У хворих першої групи усереднене значення часу моторного темпу було 529,7 $\pm 38,7$ мс ( $<<0,001)$. Отриманий показник 545,8 $\pm 23,3$ мс у другій групі був достовірним $(p<0,001)$ і демонстрував позитивний вплив фрізичної терапії. У третій групі цей показник зменшився до $558,9 \pm 24,3$ мс $(p<0,001)$.

Подібним чином можна уявити латентний період простої сенсомоторної реакції до і після впливу фрізичної терапії, усереднений для обох рук. До ії проведення у хворих першої і другої груп латентний період простої сенсомоторної реакції досягав 455,8 \pm 39,2 мс і 431,3 $\pm 28,2$ мс відповідно, що достовірно (в першій групі $\mathrm{p}<0,001$, у другій і першій $\mathrm{p}<0,01)$ перевищувало вказаний показник у здорових досліджуваних - 289,4 $\pm 16,9$ мс. Під час аналізу цього показника в третій групі, що дорівнює 433,8 $\pm 15,9$ мс, отримано також достовірні значення при порівнянні з КГ (р <0,001). Після проведеного курсу лікування час між натисканням двох клавіш у хворих зменшувався. Зменшувався латентний період простої сенсомоторної реакції в першій групі до $382,1 \pm 20,5$ мс, хоча і недостовірно порівняно зі значенням до лікування.

Результати проведеного дослідження свідчать про те, що курсове застосування фрізичної терапії на різних стадіях хвороби приводить до значного поліпшення функціонального стану

ТАБЛИЦЯ 2 - Зміна моторного і сенсомоторного темпу до і після фізичної терапії у хворих із хворобою Паркінсона, мс

\begin{tabular}{|l|c|c|c|c|}
\hline \multirow{2}{*}{\multicolumn{1}{|c|}{ Група }} & \multicolumn{2}{|c|}{ Моторний } & \multicolumn{2}{c|}{ Сенсомоторний } \\
\cline { 2 - 5 } & до ФТ & після ФТ & до ФТ & після ФТ \\
\hline Перша $(\mathrm{n}=20)$ & $706,2 \pm 44,8$ & $529,7 \pm 38,7^{* * *}$ & $455,8 \pm 39,2$ & $382,1 \pm 20,5^{\text {** }}$ \\
\hline Друга $(\mathrm{n}=26)$ & $681,6 \pm 27,2$ & $545,8 \pm 23,3^{* * *}$ & $431,3 \pm 28,2$ & $364,5 \pm 11,9^{*}$ \\
\hline Третя $(\mathrm{n}=41)$ & $745,6 \pm 31,7$ & $558,9 \pm 24,3^{* * *}$ & $433,8 \pm 15,9$ & $383,3 \pm 14,3^{*}$ \\
\hline
\end{tabular}

Примітки: ${ }^{*}-p<0,05,{ }^{* *}-p<0,01,{ }^{* * *}-p<0,001$. 
хворих і добре ними переноситься. Поліпшення об'єктивно проявляється в достовірному зниженні амплітуди ЕМГ спокою, підвищенні моторного темпу, зменшенні латентного періоду простої сенсомоторної реакції, ступеня рухових порушень за показниками універсальної шкали (UPDRS). Наші дані про сприятливий вплив фізичної терапії можна зіставити 3 одиничними відомостями 3 цього питання, наявними в спеціальній літературі, де було зазначено, що позитивна дія можлива за рахунок впливу терапевтичних вправ на підвищення рівня нейротрофрічного фактора мозку, що приводить до зниження моторних симптомів через вплив на дофамінергічні шляхи [7]. Торкаючись питання про можливий механізм впливу фізичної терапії в тому вигляді, як вона була використана в даній роботі, можна висловити припущення про те, що вплив на м'язову систему може активувати периферичні дофамінергічні і центральні норадренергічні системи. Слід припустити, що стимуляція периферичних депо дофаміну може активувати і центральні дофрамінергічні структури головного мозку.

\section{Література}

1. Баннікова РО, Брушко ВВ, Тишкевич АО. Сучасний погляд на корекцію постуральної нестійкості в осіб з хворобою Паркінсона: огляд зарубіжного досвіду [Modern view on the correction of postural instability in people with Parkinson's disease: a review of foreign experience]. Проблеми медичної і фізичної реабілітації. 2020.1: 94-95.

2. Дерягина ЛЕ. Поверхностная интерференционная електро-миография при физической нагрузке различной интенсивности [Surface interferential electromyography during physical loads of different intensity]. Сборник материалов Всероссийской научно-практической конференции. Научное электронное издание. Изд-во: Московский университет МВД России имени В. Я. Кикотя. 2019: 47-51.

3. Левин ОС. Экстрапирамидные расстройства, вчера, сегодня, завтpa [Extrapyramidal disorders, yesterday, today, tomorrow]. Сборник статей, Москва: МЕДпресс-информ; 2018.408.

4. Лукянов МВ. Клиническая електромиография. История и перспективи [Clinical electromyography. History and prospects]. Неврологический журнал.2013; 2: 53-60.

lajboxnet@gmail.com
Таким чином, після курсу лікування у хворих достовірно покращується центральна регуляція рухової активності за показниками комп'ютеризованого ЕМГ-аналізу, що виражається у зниженні амплітуди спокою згиначів і розгиначів м'язів плеча, а також у зменшенні часу рухових реакцій. Фізичну терапію рекомендовано застосовувати в комплексному патогенетичному лікуванні хворих із хворобою Паркінсона на всіх стадіях розвитку захворювання. Отримані результати дозволяють вважати доцільним застосування методу ЕМГ для оцінювання ефективності цього методу.

\section{Висновки}

1. За даними електроміографрічних досліджень, фрізична терапія у хворих з немоторними проявами хвороби Паркінсона достовірно покращує їх стан.

2. Фізичну терапію рекомендовано застосовувати в лікуванні хворих з немоторними проявами хвороби Паркінсона.

3. Отримані результати дозволяють говорити про доцільність застосування методу електроміографрічних досліджень для оцінювання ефективності фрізичної терапії при хворобі Паркінсона.

5. Карабань ИН, Луханина ЕП, Березецкая НМ. Электромиографическое исследование мышечной активности у пациентов с болезнью Паркинсона [Electromyographic study of muscle activity in patients with Parkinson's disease]. Международний неврологический журнал. 2011; 5(43):81-86.

6. Hanno Felder, Laura Steffny, Daniel Friemert. Фономиография и электромиография: взаимосвязи и различия с параметрами амплитуды и частоты [Phonomyography and electromyography: relationships and differences with amplitude and frequency parameters]. Педагогико- психологические $и$ медико-биологические проблеми физической культуры и спорта. 2018; 13 (4): $140-148$

7. Hubble RP, Naughton GA, Silburn PA, Cole MH. Trunk muscle exercises as a means of improving postural stability in people with Parkinson's 'disease: a protocol for a randomised controlled trial. BMJ Open. 2017; 4(12)

8. Jankovic J. Parkinson's disease: clinical features and diagnosis. Jankovic J. Journal of Neurology, Neurosurgery \& Psychiatry.2018;79(4):368-76. 